\title{
Sea ice microbial communities. IV. The effect of light perturbation on microalgae at the ice- seawater interface in McMurdo Sound, Antarctica
}

\author{
Anna C. Palmisano ${ }^{1}$, Steven T. Kottmeier ${ }^{1}$, Richard L. Moe ${ }^{2}$ and \\ Cornelius W. Sullivan ${ }^{1}$ \\ ${ }^{1}$ Marine Biology Research Section, Department of Biological Sciences, University of Southern California, Los Angeles, \\ California 90089-0371, USA \\ 2 Department of Botany, University of California, Berkeley, California 94704, USA
}

\begin{abstract}
In McMurdo Sound, Antarctica, an in situ light perturbation study was conducted on $1.5 \mathrm{~m}$ thick annual sea ice during the 1981 austral spring ice microalgal bloom. A $100 \mathrm{~m}^{2}$ quadrat was covered with snow to a depth of $70 \mathrm{~cm}$ reducing under ice irradiance by $97 \%$ relative to a control quadrat with $7 \mathrm{~cm}$ of natural snow cover. Samples were collected from the ice-seawater interface within each quadrat by SCUBA divers. After the first 3 wk of light perturbation (24 Oct-18 Nov 1981), net ice growth was about $20 \mathrm{~cm}$; there was no significant difference in $\mathrm{C}$ : chl a ratios in the 2 quadrats during this period. However, during the following 3 wk when net ice growth was zero (18 Nov-7 Dec 1981), C : chl a ratios dropped to 38 in control while ratios in the light perturbed quadrat remained high $(>200)$. Photosynthetic rate in the control reached a peak of $0.35 \mathrm{mg} \mathrm{C}(\mathrm{mg} \mathrm{chl} \mathrm{a})^{-1} \mathrm{~h}^{-1}$ in early December but was not detectable in the light perturbed quadrat. Facultative heterotrophy was found in natural populations of sea ice diatoms at substrate concentrations close to ambient. Respiration and incorporation of ${ }^{14} \mathrm{C}$-serine into acid-insoluble particles in the $\geq 1.0 \mu \mathrm{m}$ size fraction were found in both control and light perturbed quadrats. Variation in uptake among samples was very high, and a light effect was not detected. Microautoradiographs revealed that ice diatoms including Nitzschia sublineata Hasle, a common sea ice alga lacking epiphytic bacteria, were labeled with ${ }^{14} \mathrm{C}$-serine. Although heterotrophic carbon uptake from serine represented $<0.3 \%$ of photosynthetic carbon fixation in the control, heterotrophy may be a more important part of the carbon budget in certain species such as $N$. sublineata. Low rates of heterotrophic uptake might provide sufficient carbon and energy for maintenance metabolism during the dark winter months.
\end{abstract}

\section{INTRODUCTION}

In the 1960s, Bunt and his coworkers (Bunt, 1963; Bunt and Wood, 1963; Bunt and Lee, 1970) pioneered the study of the physiological ecology of sea-ice microalgae in the Antarctic. In recent years, the contribution of ice microalgae to overall primary production in polar oceans has attracted renewed interest (Homer, 1976; Hoshiai, 1981). Bottom ice algae, dominated by diatoms, are commonly found in the diffuse lower layers of congelation ice in the Arctic (Apollonio, 1961; Horner and Alexander, 1972) and in the Antarctic (Sullivan and Palmisano, 1981; McConville and Wetherbee, 1983; Palmisano and Sullivan, 1983a), as well as in the lower platelet ice layer in some parts of the Antarctic (Bunt and Wood, 1963; Bunt and Lee,
1970; Sullivan et al., 1983). Distinct ice algal communities may also be associated with surface melt pools (Whitaker, 1977), salinity maxima at intermediate depths in sea ice (Ackley et al, 1979), and floating ice at ice edge zones (Niebauer et al., 1981).

Standing crop estimates for bottom ice communities have been reported as high as $300 \mathrm{mg} \mathrm{chl} \mathrm{a} \mathrm{m}^{-2}$ (Palmisano and Sullivan, 1983a) which is about $75 \%$ of the theoretical maximum standing crop for diatom domi-

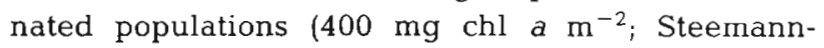
Nielsen, 1962). Seaice microalgae have been estimated to contribute as much as $25 \%$ of the productivity in the Antarctic (Hoshiai, 1981) and $50 \%$ of the productivity in nearshore areas of the Beaufort Sea in the Arctic (Alexander, 1974).

Light has been proposed as a factor controlling the 
growth of bottom ice algae (Bunt, 1971; Fogg, 1977 ; Horner and Schrader, 1982; Palmisano and Sullivan, 1982; Sullivan et al., 1983). Under-ice irradiance is typically less than $1 \%$ and often less than $0.1 \%$ of surface downwelling irradiance during the spring ice microalgal bloom (Sullivan et al., 1982); it varies in intensity on both a spatial and temporal basis. Spatial heterogeneity of bottom ice microalgae appears to be related to the attenuation of light by snow cover and sea ice. Sullivan et al. (in press) found an inverse relation between ice algal standing crops and snow depth at 8 sites in McMurdo Sound, Antarctica. Moreover, microalgae in the polar regions are subject to extreme seasonal variation in irradiance with continuous darkness in the winter and continuous light in the summer; in McMurdo Sound, these periods last $4 \mathrm{mo}$.

The purpose of our study was to examine the physiological response of microalgae at the ice-seawater interface to an artificial reduction in light intensity. Algae at the ice-seawater interface are probably the most metabolically active algae in the ice column; a temperature gradient exists from the bottom of the sea ice where temperatures are relatively warm at $-1.9^{\circ} \mathrm{C}$ (Littlepage, 1965) to the ice surface which may approach air temperatures sometimes as low as $-40^{\circ} \mathrm{C}$. Cells living higher in the ice may experience stress from freezing such as membrane damage and desiccation. Moreover, algae at the ice-seawater interface in McMurdo Sound are continually bathed in inorganic nutrients at high concentrations (Littlepage, 1965). Here we describe a controlled light perturbation study comparing a sea ice microbial community (SIMCO) with natural snow cover to a SIMCO where under-ice irradiance was reduced; manipulation of snow cover allowed us to alter in situ irradiance without using artificial enclosures. The effects of light perturbation on algal cell numbers, species composition, and algal-bacterial associations are reported elsewhere (Grossi et al., in press).

\section{METHODS}

Sample collection. Field studies were conducted at McMurdo Sound, Antarctica (Fig. 1) from 8 October 1981 to 17 December 1981. The study site was located about $50 \mathrm{~m}$ off Cape Armitage on the east side of McMurdo Sound and encompassed $200 \mathrm{~m}^{2}$ of sea ice. A $1 \mathrm{~m}$ diameter ice hole was drilled on 21 October 1981 , and a dive hut was placed over the hole to provide access to the bottom ice community by SCUBA divers. The water depth at the study site was about $20 \mathrm{~m}$.

Two $10 \times 10 \mathrm{~m}$ quadrats about $3.5 \mathrm{~m}$ apart with similar ice thickness and snow cover were designated

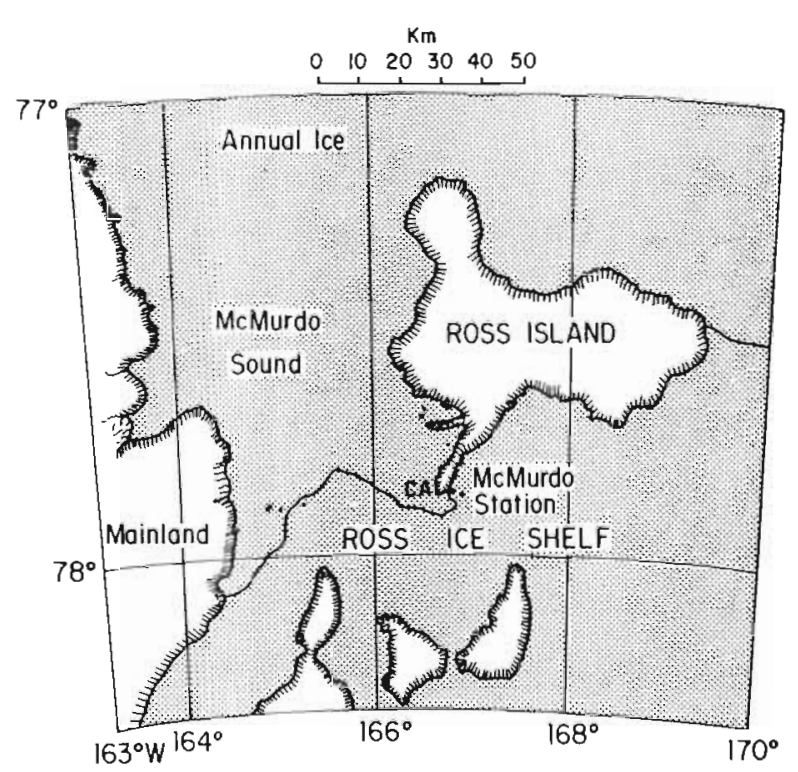

Fig. 1. Map of McMurdo Sound, Antarctica, showing study site on annual sea ice near Cape Armitage (CA)

with flags. Initial (pre-perturbation) samples were collected from both quadrats on 26 and 27 October 1981. On 29 October 1981, under-ice irradiance was reduced in an experimental quadrat by increasing the surface snow to a depth of $70 \mathrm{~cm}$. Natural snow cover in a control quadrat was about $7 \mathrm{~cm}$. Post-perturbation samples were collected after 3 and 6 wk from both control and light perturbation experiment (LPE) quadrats. Snow and ice thickness in the study area were monitored throughout the experiment.

Samples were collected by SCUBA divers from the ice-seawater interface with a wide-mouthed syringe sampler consisting of a polypropylene funnel $9 \mathrm{~cm}$ in diameter to which three $50 \mathrm{ml}$ syringes were attached by a common port. The funnel part of the sampler was pushed into the bottom ice by a diver, and the iceseawater sample was pulled into the syringes. The sample consistency was primarily liquid with only a few ice crystals several $\mathrm{mm}$ in length. Samples (except those used for in situ primary production) were returned to the darkened dive hut where they were placed in insulated, light-proof containers (Polyfoam Packers, Wheeling, Ill.) for return to the Eklund Biological Center (EBC) of McMurdo Station. Thus, the samples were protected at all times from high light and freezing temperatures during transport. At the $E B C$, samples were incubated at $-1.9^{\circ} \mathrm{C}$ in the environmental chamber described by Palmisano and Sullivan (1982). Light conditions in the chamber were calibrated to match under-ice irradiance measured by divers, and blue-green filters were used to mimic the under-ice light spectrum (Maykut and Grenfell, 1975). 
Under-ice irradiance was measured with a QSI-140 scalar irradiance meter (Biospherical Instruments, San Diego, CA). Divers held the probe directly under the annual ice and took 3 to 5 replicate readings lasting 0.5 to $1 \mathrm{~min}$ for the control quadrat and 2 to $5 \mathrm{~min}$ in the LPE quadrat.

Chlorophyll a and particulate organic carbon (POC). Aliquots of the ice-seawater interface samples were removed from the environmental chamber for the following analyses within $6 \mathrm{~h}$ of collection. The interfacial samples were liquid at time of analysis, and macroscopic ice crystals were not observed. Duplicate samples for chlorophyll $a$ and phaeopigments were collected on $25 \mathrm{~mm}$ glass fiber filters (GF/C, Whatman) and extracted in $90 \%$ acetone for 17 to $24 \mathrm{~h}$ at $4{ }^{\circ} \mathrm{C}$ in the dark. Pigment concentrations were determined with a Turner 111 fluorometer equipped with a high sensitivity door and a red-sensitive photomultiplier (Holm-Hansen et al., 1965). POC was measured by the wet oxidation techniques of Menzel and Vaccaro (1964). Triplicate aliquots of the interfacial samples were filtered onto glass fiber filters, placed in ampules, and frozen. Both filters and ampules had been precombusted at $500^{\circ} \mathrm{C}$ for $24 \mathrm{~h}$. Frozen samples were returned to the University of Southern California for analysis with an Oceanography International Corp. infrared gas analyzer (College Station, Texas).

In situ primary production. Photosynthetic rate was measured in situ in light and dark $90 \mathrm{ml}$ cylindrical Plexiglas chambers. Samples were placed in these chambers immediately upon collection, inoculated with 20 to $25 \mu \mathrm{Ci}$ (about 734 to 917 Becquerels) $\mathrm{NaH}^{14} \mathrm{CO}_{3}$ (New England Nuclear, Boston, Mass.) through a serum stoppered port, and suspended flush with the bottom of the annual ice by divers using ice pitons. Four pairs of light and dark chambers were incubated per quadrat. All samples were incubated in situ for $12 \mathrm{~h}$ (1100 to $2300 \mathrm{~h}$ ) except for the 27 October 81 samples which were incubated for $24 \mathrm{~h}$. SCUBA divers retrieved the chambers from under the ice, and the samples were promptly returned to the EBC in insulated light-proof containers. Aliquots of 10 to $25 \mathrm{ml}$ were filtered onto $1.0 \mu \mathrm{m}$ porosity membrane filters (Nuclepore) and assayed in toluene-based scintillation fluid in a Beckman LSC-100 liquid scintillation counter. Counts were corrected by the external standard ratio method.

Heterotrophic metabolism of ${ }^{14} \mathrm{C}$-serine. Uptake of ${ }^{14} \mathrm{C}$-serine was determined by the methods of Hobbie and Crawford (1969) in laboratory incubations. Uniformly labeled ${ }^{14} \mathrm{C}$-serine (New England Nuclear) was acidified to $\mathrm{pH} 2$ and bubbled with $\mathrm{N}_{2}$ prior to use to flush out possible residual ${ }^{14} \mathrm{CO}_{2}$ (Richardson and Fogg, 1982). About $0.15 \mu \mathrm{Ci}$ (about 5.5 Becquerels) of ${ }^{14} \mathrm{C}$-serine was added to $15 \mathrm{ml}$ of ice-seawater samples to produce a final concentration of added serine of 10 to $60 \mathrm{nM}$. Samples were incubated with ${ }^{14} \mathrm{C}$-serine for 20 to $24 \mathrm{~h}$ in the dark. After incubation, dissolved $\mathrm{CO}_{2}$ was released by acidification of samples to $\mathrm{pH} 2$ and adsorbed to a Whatman \#1 filter treated with phenethylamine (J. T. Baker). Radioactivity associated with these filters was designated as respiration. Incorporation of ${ }^{14} \mathrm{C}$-serine into acid insoluble particles was determined by filtering $10 \mathrm{ml}$ of the sample onto $0.2 \mu \mathrm{m}$ porosity Nuclepore filters which were then dried under an infrared lamp and assayed for radioactivity. A blank was acidified and filtered at time zero to determine background adsorption of label. To assess the possible contribution of non-attached bacteria to heterotrophy, a parallel set of samples was filtered through a $1.0 \mu \mathrm{m}$ porosity filter prior to incubation with the radiolabel.

Microautoradiography. Parallel samples were incubated for microautoradiographic analysis of ${ }^{14} \mathrm{C}$-serine uptake by a modification of the technique of Hoppe (1976). After 24 h dark incubation, samples were fixed in $1 \%$ glutaraldehyde (J. T. Baker, Reagent Grade), refrigerated at $4{ }^{\circ} \mathrm{C}$, and returned to USC for processing. Fifteen $\mathrm{ml}$ samples were filtered onto $25 \mathrm{~mm}$ diameter $1.0 \mu \mathrm{m}$ porosity membrane filters (Nuclepore), rinsed with $5 \mathrm{ml}$ distilled water, and placed on a Kodak AR10 fine grain stripping plate. Plates were exposed to radiolabeled samples for $25 \mathrm{~d}$. Autoradiographic plates were developed and photographed with a phase contrast photomicroscope. Microautoradiographs were used to provide a qualitative description of microorganisms labeled with ${ }^{14} \mathrm{C}$-serine; they were not subjected to grain density analysis.

Scanning electron microscopy (SEM). Samples were prepared for SEM on $0.2 \mu \mathrm{m}$ porosity Nuclepore filters by the methods of Paerl and Shimp (1973) except that ethanol was substituted for acetone during dehydration. Samples were critical point dried, sputter coated with gold, and examined in a scanning electron microscope as described previously (Sullivan and Palmisano, 1984).

\section{RESULTS}

In the austral fall of 1981 ice cover on McMurdo Sound broke up completely and blew out to sea. Consequently, most of the ice in the sound the following spring resulted from accumulation during one winter, and multi-year ice was scarce. The ice sampled in the present study formed in August and was thinner than in previous years when it formed earlier. The layer of platelet ice under the congelation ice at Cape Armitage was only a few cm thick in 1981; this contrasts with 1967 when Bunt and Lee (1970) reported a platelet layer up to $2 \mathrm{~m}$ in McMurdo Sound. 
Snow and ice cover (Table 1) were not significantly different in control and LPE quadrats prior to light perturbation (Student's t-test; $\mathrm{P}<0.05$ ). Snow cover decreased $6 \mathrm{~cm}$ in the control quadrat and $3 \mathrm{~cm}$ in the experimental quadrat during the course of the $6 \mathrm{wk}$ experiment. About $20 \mathrm{~cm}$ of ice accreted in both quadrats during the first $3 \mathrm{wk}$ of the experiment (24 Oct 1981 to 18 Nov 1981). There was no net ice growth, however, between 3 and 6 wk after light perturbation (18 Nov to 7 Dec 1981). Ice thickness was not significantly different in the control and LPE quadrats during the $6 \mathrm{wk}$ experiment.

Under-ice irradiance (Table 2) reflected the differences in snow cover on the 2 quadrats. Evening values in the control at 3 and 6 wk were much lower than daytime values, despite relatively constant surface irradiance. When light measurements were compared at similar times of day, under-ice irradiance in the LPE quadrat was less than $97 \%$ that of the control. Daily under-ice irradiance was consistently less than $0.3 \%$ of surface downwelling irradiance.

No significant differences in chlorophyll a and POC concentrations (Table 3) were found in the control and LPE samples prior to perturbation or after $3 \mathrm{wk}$ (Student's t-test; $\mathrm{P}<0.05$ ). At $6 \mathrm{wk}$, however, the chlorophyll concentration rose fivefold in the control but dropped by $50 \%$ in the LPE; POC was approximately 1.5 times greater in the control than the LPE. Conse-

Table 1. Snow and annual sea-ice cover at Cape Armitage, McMurdo Sound in control and light perturbation experiment (LPE). $\bar{x} \pm$ S.D. of 3 measurements

\begin{tabular}{|ccccc|}
\hline & $\begin{array}{c}\text { Date } \\
(1981)\end{array}$ & Sample & $\begin{array}{c}\text { Snow depth } \\
(\mathrm{cm})\end{array}$ & $\begin{array}{c}\text { Ice thickness } \\
(\mathrm{m})\end{array}$ \\
\hline \multirow{2}{*}{ CONTROL } & 24 Oct & Pre-perturbation & $7.2 \pm 3.5$ & $1.47 \pm 0.01$ \\
& $18 \mathrm{Nov}$ & $3 \mathrm{wk}$ & $5.1 \pm 1.6$ & $1.65 \pm 0.04$ \\
& $2 \mathrm{Dec}$ & $6 \mathrm{wk}$ & $1.5 \pm 1.0$ & $1.65 \pm 0.03$ \\
LPE & & & $7.4 \pm 2.1$ & $1.48 \pm 0.02$ \\
& 24 Oct & Pre-perturbation & $70.2 \pm 1.0$ & $1.48 \pm 0.02$ \\
& 29 Oct & Perturbation & $74.4 \pm 7.6$ & $1.68 \pm 0.08$ \\
& 18 Nov & $3 \mathrm{wk}$ & $66.8 \pm 2.9$ & $1.67 \pm 0.02$ \\
& 7 Dec & $6 \mathrm{wk}$ & & \\
& & & &
\end{tabular}

Table 2. Surface and under-ice irradiance at Cape Armitage in control and light perturbation experiment (LPE)

\begin{tabular}{|c|c|c|c|c|c|c|}
\hline & \multirow{2}{*}{$\begin{array}{c}\text { Date } \\
(1981)\end{array}$} & \multirow[t]{2}{*}{ Sample } & \multirow{2}{*}{$\begin{array}{l}\text { Time } \\
\text { (h) }\end{array}$} & \multirow{2}{*}{$\begin{array}{c}\text { Surface } \\
\mu \mathrm{E} \mathrm{m}^{-2} \mathrm{~s}^{-1}\end{array}$} & \multicolumn{2}{|c|}{ Under-ice } \\
\hline & & & & & $\mu \mathrm{E} \mathrm{m}^{-2} \mathrm{~s}^{-1}$ & $\%$ surface \\
\hline \multirow[t]{5}{*}{ CONTROL } & $26 \mathrm{Oct}$ & Pre-perturbation & $22: 00$ & 992 & 0.2 & .02 \\
\hline & 14 Nov & $3 w k$ & $10: 00$ & 1498 & 2.9 & .19 \\
\hline & & & $23: 00$ & 1410 & 0.5 & .04 \\
\hline & $3 \mathrm{Dec}$ & $6 \mathrm{wk}$ & $11: 00$ & 1528 & 2.5 & .16 \\
\hline & & & $20: 00$ & 1543 & 0.6 & .04 \\
\hline \multirow[t]{3}{*}{ LPE } & 27 Oct & Pre-perturbation & $11: 00$ & 1508 & 4.0 & .27 \\
\hline & 15 Nov & $3 w \mathrm{k}$ & $12: 00$ & 1517 & 0.1 & .005 \\
\hline & $4 \mathrm{Dec}$ & $6 \mathrm{wk}$ & $11: 00$ & 1500 & 0.2 & .01 \\
\hline
\end{tabular}

Table 3. Chlorophyll a, particulate organic carbon (POC) concentrations and photosynthetic rates in control and light perturbation experiment (LPE). $\bar{x} \pm$ S.D. of 4 samples

\begin{tabular}{|c|c|c|c|c|c|c|}
\hline & Date (1981) & Sample & $\operatorname{chl} a\left(\mu g 1^{-1}\right)$ & $\mathrm{POC}\left(\mathrm{mg} \mathrm{l}^{-1}\right)$ & C:chl a & $\mathrm{mgC}(\mathrm{mg} \mathrm{chl} \mathrm{a})^{-1} \mathrm{~h}^{-1}$ \\
\hline \multirow{3}{*}{ CONTROL } & $26 \mathrm{Oct}$ & Pre-perturbation & $5.21 \pm 2.33$ & $2.52 \pm 0.67$ & 484 & $0.165 \pm 0.143$ \\
\hline & $14 \mathrm{Nov}$ & $3 \mathrm{wk}$ & $20.1 \pm 6.6$ & $2.93 \pm 0.81$ & 146 & $0.052 \pm 0.019$ \\
\hline & $3 \mathrm{Dec}$ & $6 \mathrm{wk}$ & $111 \pm 30$ & $4.23 \pm 1.31$ & 38 & $0.346 \pm 0.127$ \\
\hline \multirow[t]{3}{*}{ LPE } & 27 Oct & Pre-perturbation & $3.54 \pm 1.00$ & $2.05 \pm 0.56$ & 579 & $0.102 \pm 0.053$ \\
\hline & 15 Nov & $3 w k$ & $14.2 \pm 12.4$ & $3.16 \pm 1.15$ & 222 & Not detectable \\
\hline & $4 \mathrm{Dec}$ & 6 wk & $6.93 \pm 2.68$ & $2.89 \pm 0.47$ & 417 & Not detectable \\
\hline
\end{tabular}


Table 4. Heterotrophic metabolism (respiration + incorporation) of ${ }^{14} \mathrm{C}$-serine in control and light perturbation experiment (LPE) in the fraction $\geq 1.0 \mu \mathrm{m}$ ( $\mu \mathrm{g}$ serine $\left.\mathrm{C}[\mathrm{mg} \mathrm{chl} a]^{-1} \mathrm{~h}^{-1}\right) . \overline{\mathrm{x}} \pm \mathrm{S}$. D. of 4 samples

\begin{tabular}{|c|c|c|c|c|c|c|}
\hline & $\begin{array}{c}\text { Date } \\
(1981)\end{array}$ & Sample & Respiration & Incorporation & Metabolism & $\begin{array}{l}\text { Heterotrophic } \\
\text { metabolism as } \\
\% \text { of photosynthetic } \\
\text { carbon fixation }\end{array}$ \\
\hline \multirow[t]{3}{*}{ CONTROL } & 26 Oct & Pre-perturbation & $0.216 \pm 0.097$ & $0.228 \pm 0.078$ & 0.444 & 0.27 \\
\hline & 14 Nov & $3 w k$ & $0.047 \pm 0.012$ & $0.073 \pm 0.046$ & 0.120 & 0.23 \\
\hline & $3 \mathrm{Dec}$ & $6 \mathrm{wk}$ & $0.023 \pm 0.009$ & $0.017 \pm 0.007$ & 0.040 & 0.01 \\
\hline \multirow[t]{3}{*}{ LPE } & 27 Oct & Pre-perturbation & $0.034 \pm 0.010$ & $0.032 \pm 0.020$ & 0.066 & 0.06 \\
\hline & 15 Nov & $3 w k$ & $0.044 \pm 0.033$ & $0.026 \pm 0.021$ & 0.070 & - \\
\hline & $4 \mathrm{Dec}$ & $6 \mathrm{wk}$ & $0.090 \pm 0.043$ & $0.073 \pm 0.030$ & 0.163 & - \\
\hline
\end{tabular}

quently, the decrease in the $C$ : chl a ratio in the control from 146 to 38 resulted from an increase in chlorophyll concentration.

Photosynthetic and heterotrophic rates were normalized on the basis of biomass (chlorophyll a) to account for potential differences in organism densities between quadrats. Chlorophyll a specific-photosyn-
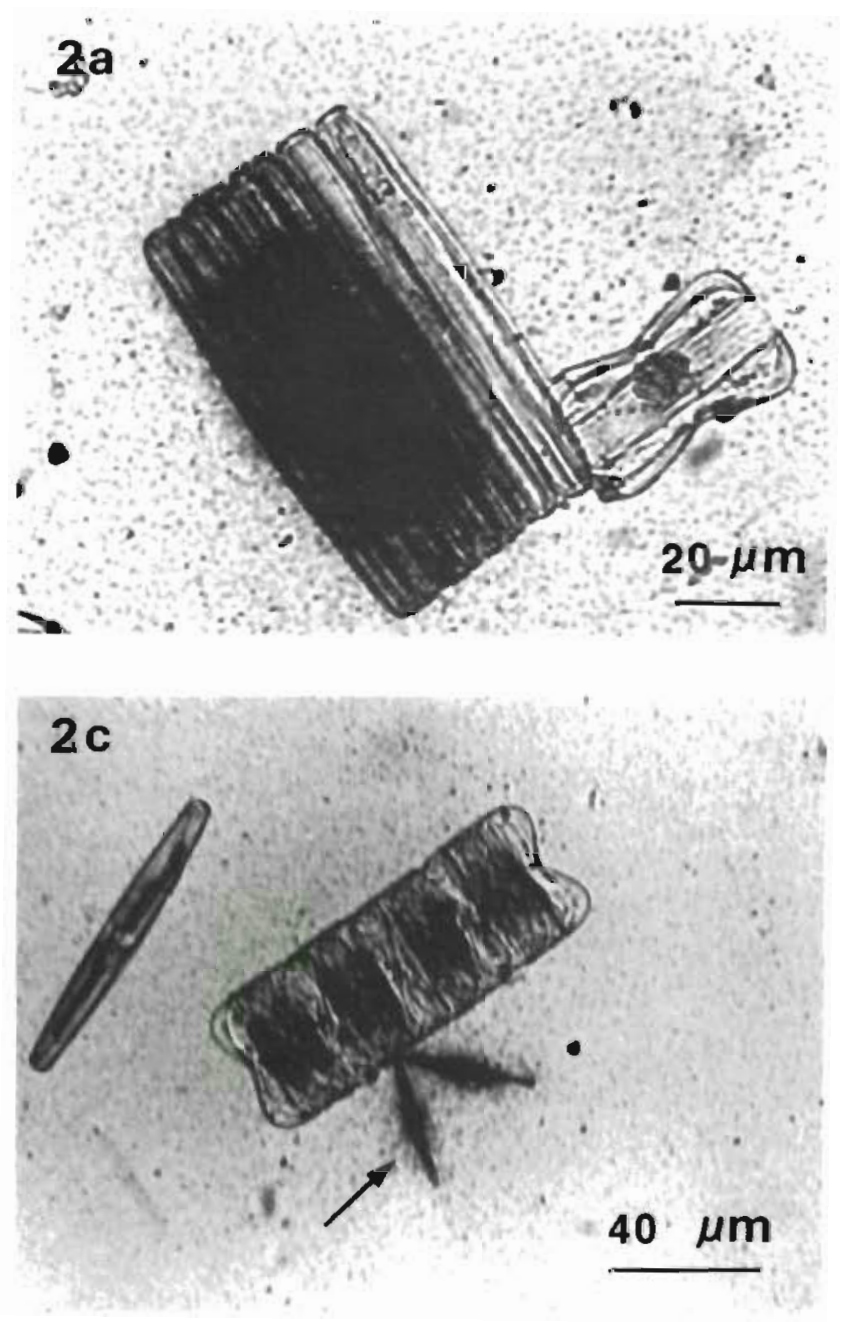

thetic rates (Table 3 ) were not significantly different (Student's t-test; $\mathrm{P}<0.05$ ) in control and LPE samples prior to perturbation. In the $6 \mathrm{wk}$ samples, photosynthetic rate in the control reached a peak of $0.35 \mathrm{mg}$ $\mathrm{C}(\mathrm{mg} \mathrm{chl} \mathrm{a})^{-1} \mathrm{~h}^{-1}$. After addition of snow cover, photosynthesis was not detectable in the LPE; light values did not exceed dark values.

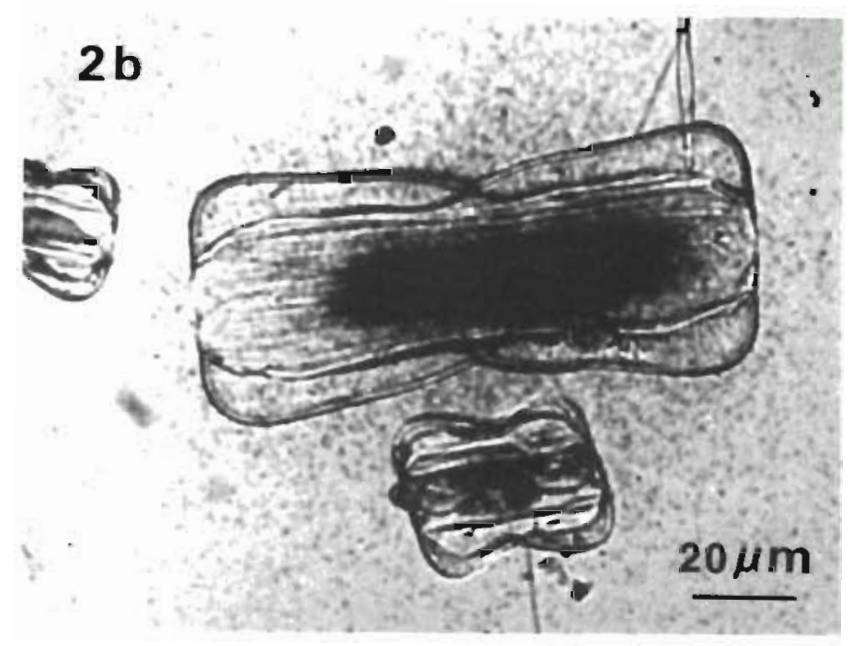

Fig. 2. Microautoradiographs of sea-ice diatoms labeled with ${ }^{14} \mathrm{C}$-serine after $24 \mathrm{~h}$ dark incubation at $-1.9^{\circ} \mathrm{C}$. (a) Chain of 5 Nitzschia sublineata $(80 \mu m)$ cells; 3 labeled cells are attached to 2 unlabeled empty frustules; (b) large Amphiprora sp. $(110 \mu \mathrm{m})$ with condensed, labeled cytoplasm; (c) arrow points to unidentified, labeled diatom $(35 \mu \mathrm{m})$ attached to small $(40 \mu \mathrm{m})$ Amphiprora sp. 
Heterotrophic metabolism of ${ }^{14} \mathrm{C}$-serine in control and LPE quadrats was determined as the sum of respiration and incorporation of ${ }^{14} \mathrm{C}$-serine (Table 4) using ambient concentrations of serine at the start of each incubation. Time zero controls were subtracted from each sample as background for label adsorption. Respiration and incorporation of ${ }^{14} \mathrm{C}$-serine by the $\leq$ $1.0 \mu \mathrm{m}$ and $\geq 0.2 \mu \mathrm{m}$ size fraction were not significantly different than time zero controls, therefore, only data for the $\geq 1.0 \mu \mathrm{m}$ fraction are presented. Variability in serine respiration and incorporation was typically high among quadruplicate samples from each date. Prior to perturbation, the mean heterotrophic metabolism was almost 6 times greater in the control than in the LPE. Within the 6 wk period, uptake varied almost 10 -fold in the control; however, carbon uptake by the heterotrophic metabolism of serine was consistently less than $0.3 \%$ of photosynthetic carbon fixation. In all cases, about $50 \pm 10 \%$ of the total serine taken up was respired. Using high performance liquid chromatography, natural concentrations of serine in ice-seawater interface samples were found to vary considerably among samples with a range from 101 to $711 \mathrm{nM}$ (D. Manahan, pers. comm.).

Microautoradiographs of diatoms labeled with ${ }^{14} \mathrm{C}$ serine are shown in Fig. 2. Silver-grain formation resulting from ${ }^{14} \mathrm{C}$-serine uptake appeared to be evenly distributed in the labeled diatoms. Three species of pennate diatoms were consistently labeled with ${ }^{14} \mathrm{C}$-serine. Nitzschia sublineata Hasle was the most common of the three (Fig. 2a); it is about $80 \mu \mathrm{m}$ in valve length and typically occurs in colonies of two to six cells adhering along their pervalver axes. $N$. sublineata cells represented about $8 \%$ of the total cell number on the microautoradiographic plates. A large Amphiprora sp. (110 $\mu \mathrm{m}$ valve length), occurring

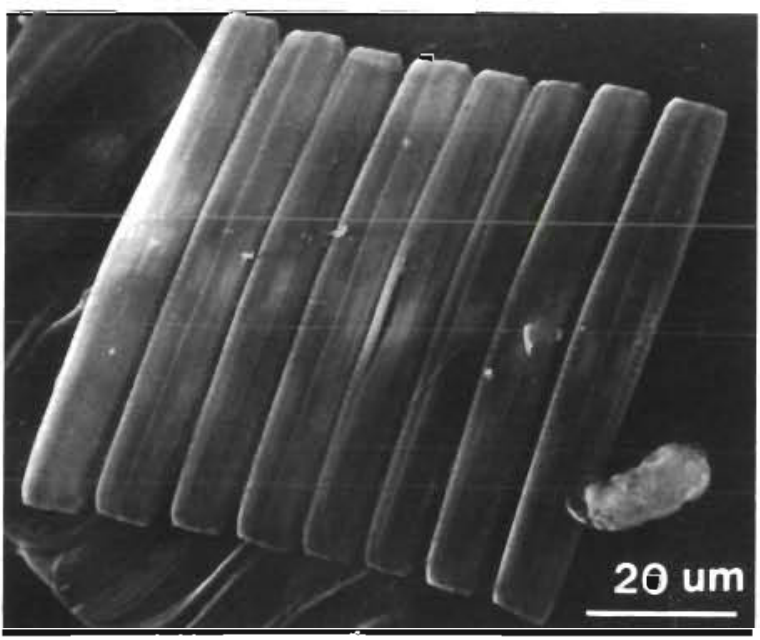

Fig. 3. Scanning electron micrograph of chain of Nitzschia sublineata showing absence of epiphytic bacteria singly and in pairs, was heavily labeled in the center of the cell possibly due to a condensed cytoplasm (Fig. 2b). An unidentified spindle-shaped pennate diatom $(35 \mu \mathrm{m})$ often seen attached to Amphiprora sp. was also labeled (Fig. 2c). The most common ice diatom species were a small $(40 \mu \mathrm{m})$ Amphiprora sp. and Nitzschia stellata Manguin; these were not labeled by ${ }^{14} \mathrm{C}$-serine (Fig. 2c). Neither formalin-killed controls nor empty diatom frustules were found labeled in microautoradiographs. Scanning electron microscopy (Fig. 3) revealed that $N$. sublineata were not usually colonized by bacteria, unlike some Amphiprora sp. (Sullivan and Palmisano, 1984).

\section{DISCUSSION}

We report here the first estimates of in situ primary production by an Antarctic bottom ice algal community. Previous estimates of Antarctic ice algal production have been based on laboratory rather than in situ incubations (Bunt and Lee, 1970; McConville and Wetherbee, 1983; Palmisano and Sullivan, 1983a). The peak photosynthetic rate at the ice-seawater interface was $0.35 \mathrm{mgC}$ (mg chl a) $)^{-1} \mathrm{~h}^{-1}$. Unfortunately, comparisons of primary production estimates in ice algae are very difficult to make among investigators due to the variety of sampling methods, incubation procedures, and means of data expression employed. Primary production expressed per unit volume of melt water, for example, can be particularly misleading. Depending on the type of ice sampled (platelet or congelation) and the amount of uncolonized ice included in the sample, algae may be more or less diluted by low salinity, ice crystal melt water which will in turn bias primary production estimates. Moreover, most current estimates of primary production in sea ice algae, including those presented here, are subject to two criticisms. First, in situ incubations of less than $24 \mathrm{~h}$ (Horner and Schrader, 1982; this study) may overestimate actual daily rates of primary production. Although Littlepage (1965) failed to find a diurnal periodicity in under-ice irradiance, our data suggest that such a periodicity does exist. Despite relatively constant surface downwelling irradiance during the spring bloom in November and December, diurnal changes in sun angle may profoundly affect under-ice irradiance (Sullivan et al., 1982). On the other hand, we may have underestimated photosynthetic rate because we did not account for loss of photosynthate by release of extracellular organic carbon. McConville and Wetherbee (1983), however, found in laboratory incubations that only $7 \%$ of the total carbon fixed by an ice algal population was released as extracellular organic carbon. 
Despite the variety of sampling and incubation procedures employed by different investigators, estimates of chlorophyll-specific primary production by bottom ice algal communities fall within a narrow range. A peak photosynthetic rate of $0.4 \mathrm{mg} \mathrm{C}(\mathrm{mg} \mathrm{chl} \mathrm{a})^{-1} \mathrm{~h}^{-1}$ was estimated by Bunt and Lee (1970) for microalgae in interstitial water from the platelet ice layer at McMurdo Sound. Using the data of Horner and Schrader (1982) for an Arctic bottom ice community, a chlorophyll-specific photosynthetic rate of $0.4 \mathrm{mg}$ $\mathrm{C}(\mathrm{mg} \mathrm{chl} \mathrm{a})^{-1} \mathrm{~h}^{-1}$ can be calculated. These values are considerably below estimates of assimilation numbers for temperate phytoplankton, which typically fall between 2 and $10 \mathrm{mg} \mathrm{C}(\mathrm{mg} \mathrm{chl} \mathrm{a})^{-1} \mathrm{~h}^{-1}$ (Falkowski, 1981).

The dynamics of ice accretion must be considered in interpreting the changes in C:chl $a$ in the $6 \mathrm{wk}$ study. During the period of net ice growth, $C$ : chl a ratios in both control and LPE quadrats were high (>146). These samples may reflect the biochemical composition of particles, including microalgae, recently added to the ice from the water column by physical processes (Garrison et al., 1983); they may have only been briefly exposed to the light regimes in the control and the LPE. During a period of constant ice thickness, however, profound differences were observed in the $\mathrm{C}: \mathrm{chl}$ a ratios in the 2 quadrats. The control value dropped to 38, a value typical of bottom ice communities (Bunt and Lee, 1970; Palmisano and Sullivan, 1983a), while the LPE value remained high. It is reasonable to assume that these differences were the result of exposure of ice algae to different light regimes. The high values of $C$ : chl a that occurred in the LPE samples and in the pre-perturbation and $3 \mathrm{wk}$ control samples suggest a predominance of detrital carbon; these ratios are greater than typically found in healthy, light-limited diatom populations. In a review of six diatom species, Darley (1977) found that C : chl a ranged from 22 to 44 in nutrient sufficient cultures. Hunter and Laws (1981) found $\mathrm{C}$ : chl a ratios of 18 to 200 in microalgal cultures with lower values associated with light-limited growth. Differences in the $\mathrm{C}: \mathrm{chl}$ a ratios between the 2 quadrats might also be explained by changes in species composition as a result of light perturbation. However, in a parallel study, Grossi et al. (in press) found that species composition of the ice-seawater interface samples was similar in the two quadrats: both were dominated by Amphiprora sp. and Nitzschia stellata. Our findings demonstrate the importance of following $C$ : chl a during the course of a bloom, a point emphasized by Banse (1977); dramatic changes in $\mathrm{C}$ : chl a occurred even in the control quadrat during a $6 \mathrm{wk}$ period.

Using the formula of Eppley (1972), a maximum growth rate of 0.086 doublings $\mathrm{d}^{-1}$ (a generation time of $8.1 \mathrm{~d})$ was calculated from the peak photosynthetic rate and $C$ : chl a ratio of 38 found in early December (Table 3). Grossi et al. (in press) observed that the largest increase in algal cell numbers in ice cores from the control occurred earlier in the bloom, between 24 October 1981 and 18 November 1981; this increase resulted in a growth rate estimate (adjusted for cell accumulation due to ice accretion alone) of 0.10 doublings $\mathrm{d}^{-2}$. Although our maximum growth rate estimates are similar in value, the time of their occurrence is not. Both growth rate estimates compare favorably with those of Bunt and Lee (1970); we calculated specific growth rates $(\mu)$ of 0.08 to 0.21 doublings $d^{-1}$ from their observations on the increase in algal cell concentrations in the platelet layer at McMurdo Sound. Growth rate estimates for ice algae typically fall below the theoretical maximum growth rate of 0.76 doublings $d^{-1}$ predicted by Holm-Hansen et al. (1977) for cells growing at $-1.8^{\circ} \mathrm{C}$ using the empirical equation of Eppley (1972).

Fogg (1977) suggested that a low compensation intensity is a critical adaptation permitting the growth of algae under ice. Bunt (1964) estimated a compensation intensity of 2.5 footcandles (about $0.5 \mu \mathrm{E} \mathrm{m}^{-2} \mathrm{~s}^{-1}$ ) for algae from the interstitial water of the ice platelet layer. In the LPE where under-ice irradiance was less than $0.1 \mu \mathrm{E} \mathrm{m}^{-2} \mathrm{~s}^{-1}$, microalgae were clearly below the compensation intensity. Microalgae in McMurdo Sound experience four months of darkness during the polar winter; they may be below compensation intensity for even longer periods due to attenuation of light by snow and ice and due to the low solar angle (Palmisano and Sullivan, 1983b).

For this reason, we looked for an algal as well as a bacterial component to heterotrophic turnover of organic substrates in SIMCOs; heterotrophy may serve as an alternative to photosynthetic metabolism during the dark winter months (Palmisano and Sullivan, 1982). Facultative heterotrophy has been proposed as a means of winter survival for subarctic phytoplankton (Rodhe, 1955), Arctic seaweeds (Wilce, 1967), and sea ice microalgae (Allen, 1971). Horner and Alexander (1972) concluded that heterotrophic metabolism of ${ }^{14} \mathrm{C}$ glycine, ${ }^{14} \mathrm{C}$-glucose and ${ }^{3} \mathrm{H}$-acetate by Arctic sea ice microalgae was negligible. Their study was conducted at Point Barrow, Alaska in March, however, when increasing light levels may have already triggered a switch from heterotrophic to photosynthetic metabolism. Palmisano and Sullivan (1982) found that dark heterotrophy by 3 sea-ice diatom isolates was greatly enhanced in cells preconditioned by a $6 \mathrm{~d}$ dark incubation.

The amino acid serine was chosen to test for dark heterotrophy in natural populations of sea ice microalgae because it is an important component of dissol- 
ved organic matter in seawater (Williams, 1975). It is unlikely that serine was used by algae at the iceseawater interface as a nitrogen source due to the high concentrations of inorganic nitrogen (26.7 $\mu \mathrm{M} \mathrm{NO} \mathrm{NO}_{3}$; $\left.2.23 \mu \mathrm{M} \mathrm{NH}_{4}^{+}\right)$in seawater at Cape Armitage in 1981 (Palmisano, 1982). About $50 \%$ of the ${ }^{14} \mathrm{C}$-serine was respired, demonstrating that serine was being actively metabolized. Our estimate of ${ }^{14} \mathrm{C}$-serine uptake as the sum of respiration and incorporation of label into acid insoluble fractions is probably conservative because we did not account for acid soluble pools. To distinguish algal from bacterial heterotrophic metabolism of ${ }^{14} \mathrm{C}$-serine in the dark, two methods were employed in conjunction: differential filtration and microautoradiography. All of the uptake measured was found in the $\geq 1.0 \mu \mathrm{m}$ size fraction; uptake was not detectable in the $\leq 1.0 \mu \mathrm{m}$ and $\geq 0.2 \mu \mathrm{m}$ fraction which is dominated by non-attached ice bacteria (Sullivan and Palmisano, 1984). The $\geq 1.0 \mu \mathrm{m}$ fraction contained $100 \%$ of the total chlorophyll a (Palmisano, unpubl.) but only $16 \%$ of the total bacteria (S. Grossi, pers. comm.). Bacteria retained on the $1.0 \mu \mathrm{m}$ filter were attached to particles including diatoms; they were primarily associated with diatoms of the genus Amphiprora (Sullivan and Palmisano, 1984; Grossi et al., in press). Recently, McConville and Wetherbee (1983) reported that $>94 \%$ of the turnover of ${ }^{3} \mathrm{H}$ amino acids by a bottom ice community near East Antarctica was in the $\geq 2 \mu \mathrm{m}$ size fraction. They attributed this turnover to epibacterial communities associated with sea ice microalgae; however, data from differential filtration alone are insufficient to distinguish epibacterial from algal heterotrophic uptake (Faust and Correll, 1977).

Microautoradiography can be used as a tool to determine which components of a microbial community take up radiolabeled substrates (Hoppe, 1976; Pollingher and Berman, 1976). Microautoradiographs revealed that certain sea-ice diatom species, including Nitzschia sublineata, were heavily labeled with ${ }^{14} \mathrm{C}$ serine relative to formalin-killed controls. Light and electron microscopy showed that $N$. sublineata was not usually colonized by attached bacteria; therefore, heterotrophic uptake of serine may be attributed to the diatom itself. $N$. sublineata represented $8 \%$ of the total diatom assemblage at Cape Armitage and has been found both in the sea ice and the water column in other parts of the Southern Ocean (Hendey, 1937).

We were unable to detect an enhancement of heterotrophic metabolism in the darkened quadrat relative to the control; heterotrophic uptake in the control varied considerably during the course of the experiment. Although heterotrophic carbon uptake from serine represented less than $0.3 \%$ of photosynthetic carbon fixation in the control, it is difficult to assess the overall importance of heterotrophy in the carbon budget of ice algae. First, microautoradiographs indicated that heterotrophy may be species specific, i.e. it may be a more important part of the carbon budget in species such as Nitzschia sublineata. Second, other organic substrates not tested here, such as glutamate, glucose, and acetate (Hellebust and Lewin, 1977), may be more readily assimilated by ice algae than serine. And third, even low rates of heterotrophic carbon assimilation may be sufficient to provide carbon and energy for maintenance metabolism during the dark winter months (Palmisano and Sullivan, 1982). We do not wish to imply that bacterial heterotrophs are not active in SIMCOs: using microautoradiography, Sullivan et al. (in press) demonstrated that both free and attached ice bacteria take up a variety of ${ }^{3} \mathrm{H}$-amino acids, ${ }^{3} \mathrm{H}$-glucose, and ${ }^{3} \mathrm{H}$-thymidine under in situ and simulated in situ conditions. However, further research is needed to determine the relative importance of algal heterotrophy in SIMCOs.

Acknowledgements. The authors thank Dr. Donald Manahan for providing amino acid data, Dr. Manahan and Sarah McGrath Grossi for critically reviewing the manuscript, Dr. Greta Fryxell for identifying Nitzschia sublineata Hasle, and the US Naval Support Force in Antarctica and ITT Antarctic Services for logistic support. This study was supported by National Science Foundation grant DPP 79-20802.

\section{LITERATURE CITED}

Ackley, S. F., Buck, K. R., Taguchi, S. (1979). Standing crop of algae in the sea ice of the Weddell Sea region. Deep Sea Res. 26A: 269-381

Alexander, $V$ (1974). Primary productivity regimes of the nearshore Beaufort Sea with reference to the potential role of ice biota. Symposium on the Beaufort Sea, Coastal and Shelf Research. Arctic Institute of North America, Arlington, VA, p. 609-632

Allen, M. B. (1971). High-latitude phytoplankton. Ann. Rev. of Ecology and Systematics, p. 261-276

Apollonio, S. (1961). The chlorophyll content of Arctic sea ice. Arctic 14: 197-200

Banse, K. (1977). Determining the carbon-to-chlorophyll ratio of natural phytoplankton. Mar. Biol. 41: 199-212

Bunt, J. S. (1963). Diatoms of Antarctic sea ice as agents of primary production. Nature, Lond. 199: 1254-1257

Bunt, J. S. (1964). Primary productivity of undersed ice in Antarctic waters. 2. Influence of light and other factors on photosynthetic activities of Antarctic marine microalgae. Antarct. Res. Ser. 1: 27-31

Bunt, J. S. (1971). Microbial productivity in the polar regions. Symposia of the Society for General Microbiology XXI. Microbes and Biological Productivity, p. 333-353

Bunt, J. S., Lee, C. C. (1970). Seasonal primary production in Antarctic sea ice at McMurdo Sound in 1967. J. mar. Res. 28: $304-320$

Bunt, J. S., Wood, E. J. F. (1963). Microalgae and Antarctic sea ice. Nature, Lond. 199: 1254-1255

Darley, W. M. (1977). Biochemical composition. In: Werner, D. (ed.) The biology of diatoms. University of Calufornia Press, Berkeley and Los Angeles, p. 198-233 
Eppley, R. W. (1972). Temperature and phytoplankton growth in the sea. Fish. Bull. U.S. 71: 1063-1085

Falkowski, P. G. (1981). Light-shade adaptation and assimilation numbers. J. Plankton Res. 3: 203-216

Faust, M. A., Correll, D. R. (1977). Autoradiographic study to detect metabolically active phytoplankton and bacteria in the Rhode River estuary. Mar. Biol. 41: 293-305

Fogg, G. E. (1977). Aquatic primary production in the Antarc tic. Philos. Trans. R. Soc. Lond. (B) Biol. Sci. 279: 27-38

Garrison, D. L., Ackley, S. F., Buck, K. R. (1983). A physical mechanism for establishing algal populations in frazil ice Nature, Lond. 306: 363-365

Grossi, S. M., Kottmeier, S. T., Sullivan, C. W. (in press). Sea ice microbial communities III. The seasonal development of algal-bacterial interactions in McMurdo Sound, Antarctica. Microb. Ecol.

Hellebust, J. A., Lewin, J. (1977). Heterotrophic nutrition. In: Werner, D. (ed.) The biology of diatoms. University of California Press, Berkeley and Los Angeles, p. 169-197

Hendey, N. I. (1937). The plankton diatoms of the Southern Seas. Discovery Rep. 16: 151-364

Hobbie, J. E., Crawford, C. C. (1969). Respiration corrections for bacterial uptake of dissolved organic compounds in natural waters. Limnol. Oceanogr. 14: 528-532

Holm-Hansen, O., El Sayed, S. A., Franceschini, B. A., Cuhel R. (1977). Primary production and the factors controlling phytoplankton growth in the Antarctic seas. In: Llano, G. A. (ed.) Adaptations within Antarctic ecosystems. Gulf Publishing Co, Houston, p. 11-50

Holm-Hansen, O., Lorenzen, C. J., Holmes, R. W., Strickland, J. D. H. (1965). Fluorometric determination of chlorophyll. Cons, int. Explor. 30: 3-15

Hoppe, H.-G. (1976). Determination and properties of actively metabolizing heterotrophic bacteria in the sea, investigated by means of micro-autoradiography. Mar. Biol. 36 291-302

Horner, R. A. (1976). Sea ice organisms. Oceanogr. mar. Biol. A. Rev. 14: 167-182

Horner, R. A., Alexander, V. (1972). Algal populations in Arctic sea ice: an investigation of heterotrophy. Limnol. Oceanogr. 17: 454-458

Horner, R. A., Schrader, G. C. (1982). Relative contributions of ice algae, phytoplankton, and benthic microalgae to primary production in nearshore regions of the Beaufort Sea. Arctic 35: 485-503

Hoshiai, T. (1981). Proliferation of ice algae in Syowa Station area, Antarctica. Mem. Natl. Inst. Polar Res. Ser. E. No. 34, p. $1-12$

Hunter, B. L., Laws, E. A. (1981). ATP and chlorophyll a as estimators of phytoplankton carbon biomass. Iimnol. Oceanogr. 26: 944-956

Littlepage, J. L. (1965). Oceanographic investigations in McMurdo Sound, Antarctica. Antarct. Res. Ser. 5: 1-37

Maykut, G. A., Grenfell, T. C. (1975). The spectral distribution of light beneath first-year sea ice in the Arctic Ocean. Limnol. Oceanogr. 20: 554-563

McConville, M. J., Wetherbee, R. (1983). The bottom-ice microalgal community from annual ice in the inshore waters of East Antarctica. J. Phycol. 19; 431-439

Menzel, D. W., Vaccaro, R. F. (1964). The measurement of dissolved organic and particulate carbon in seawater. Limnol. Oceanogr. 9: 138-142

Niebauer, H. J., Alexander, V., Cooney, R. T. (1981). Primary production at the Eastern Bering Sea ice edge: the physi- cal and biological regimes. In: Hood, D. W., Calder, J. A (ed.) The eastern Bering Sea shelf: oceanography and resources, Vol. II. Inst. Mar. Sci., Univ. of Alaska, p. $763-772$

Paerl, H. W., Shimp, S. L. (1973). Preparation of filtered plankton and detritus for study with scanning electron microscopy. Limnol. Oceanogr. 18: 802-805

Palmisano, A. C. (1982). Physiology of sea ice diatoms strategies for winter survival. Ph. D. dissertation, University of Southern California

Palmisano, A. C., Sullivan, C. W. (1982). Physiology of sea ice diatoms: I. Response of three polar diatoms to a simulated summer-winter transition. J. Phycol. 18: 489-498

Palmisano, A. C., Sullivan, C. W. (1983a). Sea ice microbial communities (SIMCOs) I. Distribution, abundance, and primary production of ice microalgae in McMurdo Sound in 1980. Polar Biol. 2: 171-177

Palmisano, A. C., Sullivan, C. W. (1983b). Physiology of sea ice diatoms II. Dark survival of three polar diatoms. Can J. Microbiol. 29: 157-160

Pollingher, U., Berman, T. (1976). Autoradiographic screening for potential heterotrophs in natural algal populations of Lake Kinneret. Microb. Ecol. 2: 252-260

Richardson, K., Fogg, G. E. (1982). The role of dissolved organic material in the nutrition and survival of marine dinoflagellates. Phycologia 21: 17-26

Rodhe, W. (1955). Can plankton production proceed during winter darkness in subarctic lakes? Verh. int. Verein. (theor. angew.) Limnol. 12: 117-122

Steemann-Nielsen, E. (1962). On the maximum quantity of plankton chlorophyll per surface unit of a lake or the sea. Int. Rev. Hydrobiol. 47: 333-338

Sullivan, C. W., Palmisano, A. C. (1981). Sea ice microbial communities in McMurdo Sound, Antarctica. Antarct. J. U.S. $16: 126-127$

Sullivan, C. W., Palmisano, A. C. (1984). Sea ice microbial communities (SIMCO): distribution, abundance, and diversity of ice bacteria in McMurdo Sound, Antarctica. Appl. environ. Microbiol. 47: 788-795

Sullivan, C. W., Palmisano, A. C., Kottmeier, S. T., Grossi, S., Moe, R., Taylor, G. T. (1983). The influence of light on development and growth of sea ice microbial communities in McMurdo Sound, Antarctica. Antarct. J. U.S. 18: $100-102$

Sullivan, C. W., Palmisano, A. C., Kottmeier, S., McGrath Grossi, S., Moe, R. (in press). The influence of light on the sea ice microbial community in McMurdo Sound. In: Siegfried, W. R. (ed.) Proceedings of the SCAR symposium on Antarctic biology, Wilderness, South Africa. SpringerVerlag, Heidelberg

Sullivan, C. W., Palmisano, A. C., Kottmeier, S., Moe, R. (1982). Development of the sea ice microbial communities (SIMCO) in McMurdo Sound, Antarctica. Antarct. J. U.S. 17: $155-157$

Whitaker, T. M. (1977). Sea ice habitats of Signy Island (South Orkneys) and their primary productivity. In: Llano, G. A. (ed.) Adaptations with Antarctic ecosystems. Gulf Publishing Co., Houston, p. 75-83

Wilce, R. T. (1967). Heterotrophy in Arctic sublittoral seaweeds: an hypothesis. Botanica mar. 10: 185-197

Williams, P. J. le B. (1975). Biological and chemical aspects of dissolved organic material in seawater. In: Riley, J. P., Skirrow, G. (ed.) Chemical oceanography, Vol. II. Academic Press, London, p. 301-363 